\title{
Ayurvedic Management of Sandhivata (Janu Sandhi): A Case Report
}

\author{
Parveen Kumar*
}

Asstt. Prof. Deptt. of Panchkarma. Dayanand Ayurvedic College, Jalandhar. Punjab.

\begin{abstract}
Sandhigata Vata is a disease of the elderly. Life style, excessive weight, trauma and diet deficient in calcium are some of the risk/causative factors. Rooksha Aahar and ativyaama cause vitiation of vaata. It mainly affects weight-bearing joints of the body specially knee, hip, lumbar spine. Being commonest form of articular disorders, sandhigata vata poses a huge hindrance in day to day activities of the sufferer like walking, dressing and bathing etc. The common presentation of the disease is in the form of Shula, Sotha, Vata poornadriti sparsha and difficulty in flexion and extension of the Sandhi. Available treatment options include use of NSAID's, calcium supplementation and ultimately joint replacement. Here is a case of bilateral knee Osteoarthritis who was advised arthroplasty. After completion of the therapy, significant improvement was seen in pain, swelling, range of movement and walking distance. The patient was successfully managed with internal medication \& Janu basti therapy. With increasing towards ayurveda, a large number of patients, after taking allopathic treatment for long durations, are coming to the Ayurveda hospitals and find very good relief. It can be concluded that severe osteoarthritis may be managed with Ayurvedic intervention and use of baahyaparimaarjana chikitsa requires to be exploited to a greater extent owing to its higher safety and efficacy profile.
\end{abstract}

\section{Introduction}

Knee osteoarthritis (OA) is the most common type of arthritis and is a major cause of disability which reduced the quality of life ${ }^{1}$. The clinical features of Sandhigatavata is described in various Ayurvedic ancient text which is characterized by shula (joint pain), shotha (swelling), prasaarana-aakunchanayo pravruttischa vedana (painful joint movement) and Vatapurnadritisparsa (coarse crepitation), resembles with Osteoarthritis ${ }^{2,3,4}$. Main causative factors responsible for Sandhigata Vata are Ruksha aahara, Atimaithuna, Ativyayama (excessive exercise/work), Sheeta bhojana (cold food/drinks), Dhatukshaya and Roga Atikarshana $^{5,6}$. This condition closely resembles with knee osteoarthritis. Osteoarthritis is the most common form of arthritis. It is strongly associated with ageing, and is a major cause of disability in older people ${ }^{7}$ According to modern science loss of estrogen during menopause increase the woman risk of getting osteoarthritis ${ }^{8}$. Osteoarthritis is degenerative in nature. It is characterized by progressive disintegration of articular cartilage, formation of new bone in the floor of the cartilage lesions (eburnation) and at the joint margins (osteophytes), and leads to chronic disability at older ages ${ }^{9}$. India is expected to be the chronic disease capital with 60 million people with arthritis by 2025. Currently in OA affected persons, 80\% are having some movement limitation and $20 \%$ are unable to perform major activities of daily living ${ }^{10}$. It has been postulated that age, gender, body weight, repetitive trauma and genetic factors are the risk factors which play an important role in the manifestation of $\mathrm{OA}^{11}$. Treatment options available for sandhigata vata are snehana (oleation), swedan (sudation), upanaha (poultice) and lepa (topical application) ${ }^{12}$. Janu Sandhigata Vata is an Asthi-Sandhigata Vyadhi, where there is kshaya of Asthi Dhatu due to insufficient supply of Poshaka Rasa ${ }^{13}$. The line of treatment for sandhivata is mainly focused on the alleviation of vata dosha. Vitiated vata dosha can be best treated with the use of oil ${ }^{14}$. Use of snehana with swedana over the affected part is also advised in the treatment of vatavyadhi which alleviates pain, stiffness and improves flexibility ${ }^{15}$. 


\section{Janu basti}

It is a specialized procedure in ayurveda, especially indicated for janu sandhigata vata. There is no direct reference and description of janu basti in classical ayurvedic texts. It is like a supportive ayurvedic therapy. Janu basti can be considered as bahirparimarjana chikitsa ${ }^{16}$ as it is a type of bahya snehana and swedana (external oil application and sudation). In different opinion, janu basti is also considered as snigdha sweda. Different types of medicated oils are used in janu basti according to the disease. Mahanarayana taila is a well known ayurvedic formulation that has been indicated in the treatment of different types of vatavyadhi ${ }^{17}$. Thus janu basti with mahanarayana taila has been taken for the present case study.

\section{Case Report}

A 61 year old male patient came to panchakarma OPD of Dayanand Ayurvedic College, Jalandhar, with the complaints of Sandhi shoola i.e. severe pain and swelling over both knee joints \& difficulty in walking since 3 years. The patient was taking allopathic treatment, but did not get significant relief. He was being prescribed NSAIDS, and was advised to get knee replacement done by orthopaedic surgeons. Examination of the patient revealed Sandhi shotha (swelling) around both knee joints, Tenderness 2+, Vatapurnadritisparsa (audible crepitus) in both knee joints. The extension and flexion movements at both the knee joints were restricted, and the movements were limited to $105^{\circ}$ for flexion and extension was limited to $35^{\circ}$. Patient was underweight, had slight pallor, vitals: Pulse rate $74 / \mathrm{min}$, regular; Blood pressure was $122 / 70 \mathrm{~mm}$ of $\mathrm{Hg}$. X-ray of the joints revealed joint space reduction in both the knee joint, more so in the medial compartment in right knee joint. On the basis of the clinical features and radiological findings, the diagnosis of Osteoarthritis was established. In consideration with the findings of clinical examination \& investigations following treatment was given as table no. 1.

\section{Table No. 1: Treatment plan}

\begin{tabular}{|c|c|c|c|}
\hline Sr.No. & Treatment & Dose & Duration \\
\hline 1 & Cap Ayucal P & $250 \mathrm{mg}$ BD with milk after meals & 30 days \\
\hline 2 & Cap Shallaki & $400 \mathrm{mg}$ BD After meals & 30 days \\
\hline 3 & Panchtikta Ghrita Guggul & $1 \mathrm{gm}$ thrice a day after meals & 30 days \\
\hline 4 & Janu Basti & & 15 days \\
\hline
\end{tabular}

Each capsule of Ayucal P contains praval pishti $250 \mathrm{mg}$. Each capsule of Shallaki contains extract of Shallaki $400 \mathrm{mg}$. Panchtikta Ghrita Guggul was according the reference of Bhaishajya Ratnavali ${ }^{18}$.

\section{Janu basti:}

\section{Materials Required:}

For the present study, the following materials are required for each therapy session-

1. Masha (black gram) flour $-1 \mathrm{~kg}$

2. Mahanarayana taila $-500 \mathrm{ml}$

3. Dashmoola kwath - 2 litres (for nadi swedana),

4. Spatula - 01

5. Small piece of sponge -01

6. Water - as per requirement

7. Nadi swedana yantra (Local steam apparatus) - 01

\section{Method}

Procedure of janu basti - Firstly, masha pishti is prepared by adding sufficient quantity of water. Then, patient is asked to lye supine on the table with extended knee joint. Knee joint is properly exposed and gentle abhyanga is done over the lower limbs. After this, masha pishti is applied as a circular boundary wall with height of 4 angula over the knee joint. This circular boundary of masha pishti is allowed to settle for 5$10 \mathrm{~min}$. This is known as basti yantra. Heated mahanarayana taila is poured in the basti yantra up to the 
level of 2 angula by using small piece of cotton. The temperature of the oil should be such that it can be well tolerated by the patient. As the oil starts cooling with time, it should be replaced with warm oil to maintain the temperature. Precaution should be taken for any oil leakage from basti yantra. This procedure is carried out for 30 minutes. After this, oil is drained out from the basti yantra and boundary wall of masha pisti is removed.

Gentle abhyanga was done over the knee joint after Janu basti. After this, nadi swedana with dashmoola $k w a t h a$ over the knee joint is given to the patient 15 minutes.

\section{OBSERVATION \& RESULT}

Table no. 3 - Assessment on Day 1, 15 \& 30

\begin{tabular}{|l|l|l|l|l|}
\hline Sr No & $\begin{array}{l}\text { Assessment } \\
\text { Parameter }\end{array}$ & Day 1 & Day 15 & Day 30 \\
\hline 1. & Haemoglobin & $11.1 \mathrm{gm} / \mathrm{dl}$ & $11.2 \mathrm{gm} / \mathrm{dl}$ & $11.1 \mathrm{gm} / \mathrm{dl}$ \\
\hline 2. & ESR (Fall in $1^{\text {st }}$ hour) & $42 \mathrm{~mm}$ & 38 & 26 \\
\hline 3. & Vatapurnadritisparsa & Audible crepitus & Palpable crepitus & Mild Palpable crepitus \\
\hline 4. & Shotha & Moderate & Mild & Absent \\
\hline 5. & Sandhi shoola & Severe & Mild & Mild \\
\hline 6. & $\begin{array}{l}\text { Prasaranakkunchana } \\
\text { pravriti savedana }\end{array}$ & $\begin{array}{l}\text { Prevent complete } \\
\text { flexion }\end{array}$ & $\begin{array}{l}\text { Pain with winching } \\
\text { of face }\end{array}$ & $\begin{array}{l}\text { Pain without winching of } \\
\text { face }\end{array}$ \\
\hline 7. & Walking Distance & 50 Meters & 75 Meters & 800 Meters \\
\hline
\end{tabular}

After treatment with Janu basti for 15 days and with medicines for 1 month, patient reported very good relief in all the symptoms.

\section{Discussion}

Tab Ayucal P contains praval pishti, which is a natural source of organic calcium. Calcium is the fifth most abundant element in the body. Calcium is an important mineral component of our diet. Calcium supplementation can play a valuable role in bone health throughout the lifecycle. An adequate calcium intake through proper selection of calcium salt is therefore only one of many measures to ensure a healthy skeleton ${ }^{19}$.

Shallaki possesses tikta (bitter), madhura (sweet) and kashaya (astringent) rasa (taste); guna (quality) of Shallaki is ruksha (dry), laghu (light) and tikshna; vipaka (post-digestive effect) is katu (pungent); whereas virya (strength or effect) is ushna. The doshakarma is kapha-pitta shamaka. Shallaki has potent vatakaphahara properties ${ }^{20,21}$. Shallaki inhibits the activity of the enzyme 5 lipoxygenase through a non-redox reaction in $\mathrm{OA}^{22}$. The key constituents of Shallaki are volatile oil (4-8\%), acid resin (56-65\%) and gum (20$36 \%)$. The triterpenoids are the active constituents and are collectively called boswellic acids. The gum resin of B. serrata usually contains $43 \%$ boswellic acids, which contain a combination of six major constituents, mainly 3 acetyl, 11 keto, boswellic acids (AKBA), which help to preserve the structural integrity of joint cartilage and maintain a healthy immune mediator cascade at a cellular level ${ }^{23}$, which is active against pain and inflammation by inhibiting leukotriene synthesis.

Panchtikta Ghrita Guggul is a complex compound containing many herbs and guggul. Classical references and clinical suggest it is highly beneficial in the management of Sandhivata ${ }^{24}$.

Janu basti relieves pain, stiffness and swelling associated with arthritis and other painful conditions, pacifies the morbidity of Vata in the affected joints, muscles and soft tissues. Janu basti with mahanarayana tail followed by dashmoola kwath nadi-swedana is very effective in the management of janu sahdhigata vata ${ }^{25}$.

\section{Conclusion}

Osteoarthritis is a very common condition. Advancing age and life style factors contribute in tandem to increase the trouble. Management requires multifactorial approach including lifestyle modifications, 
exercises, drugs to relieve pain and inflammation. Ayurvedic treatments that include external application of drugs, like janu basti, offer advantage of immediate relief and negligible adverse effects. Patient treated and presented as this case study got remarkable relief with Janu basti and some common ayurvedic drugs. Therefore it can be concluded that use of baahyaparimarjan chikitsa (classical external Ayurvedic treatment) in the background of accurate diagnosis can cure the patients suffering from osteoarthritis. Being safe, devoid of adverse effects, ayurvedic management is the only option to avoid painful intervals, advancement of the disease and repeated use NSAIDs. Delaying of surgical intervention by few years by external Ayurvedic treatments is considered as great relief by the patients. Use of external therapies like Janu basti offers additional advantage of reducing systemic exposure due to oral use of medications. This study will encourage further research in the field with evidence based methodology.

\section{Referances:}

1. Sprangers MA, De Regt EB, et al. Which chronic conditions are associated with better or poorer quality of life? J Clin Epidemiol 2000; 53(9): 895-907.

2. Chopra A, Patil J, Bilampelly V, Relwani J, Tandale HS. The Bhigwan (India) COPCORD: Methodology in first information report. APLAR J Rheumatol 1997;1:145-54.

3. Hinman RS, Bennel $\mathrm{K}$ et al. Delayed onset of quadriceps activity and altered knee joint kinematics during stair stepping in individuals with knee osteoarthritis. Arch Physical Medicine Rehabillitation 2002; 83: 1080-6.

4. Trikamji Yadavji Acharya, Agniveshakrita Charaka Samhita,Chakrapani Commentary. Reprint. Chaukhambha Surbharti Prakashan Chikitsasthan. Varanasi. 2011; 618.

5. Agnivesa, Caraka Samhita by Prof Priya vrat Sharma Vol-II 7th ed. Chaukhamba Orientalia. Varanasi:; 2005: 462.

6. Dr. Madham Shetty Suresh Babu, YogaRatnakara, Purvardham-Vol-I, 2nd ed. Chaukamba Sanskrit Series. Varanasi: 2011;602.

7. Davidson medicine, edited by Brian R walker, Nicki R, College, Stuart H, Ralston, Ian D Penmon, 22nd edition. 2014;1081.

8. Obstetric \& Gynecologic diagnosis and treatment edited by Alan H .Decherney \& martin L Pernoll 18th Edn: 1036.

9. Gucclcone AA, Felson DT, Anderson JJ, Anthony JM, Zhang Y, Wilson PW, et al. The effect of specific medical condition on the functional limitations of elders in the Framingham study. Am J Public Health 1994;84:351-8.

10. Ringdahl E, Pandit S. Treatment of knee osteoarthritis. Am Fam Physician 2011; 83:1287- 92.

11. Pai XC, Rymer WZ, Chang RW, Sharma L. Effect of age and osteoarthritison kneeproprioception. Arthritis Rheum 1997;40:2260-5.

12. Sri Brahma Sankar Mishra. Bhavaprakasha Nighantu of Bhavamishra, Madhyam khanda, chapter 24 verse no. 259, 12 th edition, Varanasi; Chaukhamba Sanskrit Bhavan.2012:265.

13. Acharya JT. Charaka Samhita of Agnivesha. Edn $1^{\text {st }}$. Chaukhamba Sanskrit Sansthan. Varanasi; 2011:618.

14. Acharya Y T. Agniveshakrita Charaka Samhita, Chakrapani Commentary Chaukhambha Surbharti Prakashan. Varanasi. 2011; 624.

15. Acharya Y T. Agniveshakrita Charaka Samhita,Chakrapani Commentary, Chaukhambha Surbharti Prakashan. Varanasi: 2010;620.

16. Trikamji Yadavji Acharya, Agniveshakrita Charaka Samhita,Chakrapani Commentary. Chaukhambha Surbharti Prakashan. Varanasi, Reprint 2011;78.

17. Shastri Ambikadutta, Bhaishajya ratnawali by Goving Das. Chaukhamba prakashan. Varanasi; 560.

18. Mishra S N. Bhaishajya Ratnavali of Kaviraj Govind Das Sen. Part I. Chaukhambha Surbharti Prakashan, Varanasi; 2005; 882.

19. Trailokya A, Srivastava A, Bhole M, Zalte N. Calcium and Calcium Salts. Journal of The Association of Physicians of India. Vol. 65; 2017:100-103.

20. Pande G S, Chunekar K C. Bhava Prakasha of Bhavmishra. Chaukhamba Bharti Academy, Varanasi: $2006 ; 212$. 
21. Pande G S, Chunekar K C. (2006) Bhava Prakasha of Bhavmishra. Chaukhamba Bharti Academy, Varanasi. 2006:521.

22. Dev SA, Selection of Prime Ayurvedic Plant Drugs: Ancient-modern Concordance. New Delhi: Anamaya Publishers; 2006:113-117.

23. Kimmatkar N, Thawani V, Hingorani L, Khiyani R. Efficacy and tolerability of Boswellia serrata extract in the treatment of osteoarthritis of knee: A randomized double blind placebo controlled trial. Phytomedicine. 2003:37.

24. Akhtar B, Mahto R R, Dave A R, Shukla V D. Clinical study on Sandhigata Vata w.s.r. to Osteoarthritis and its management by Panchtikta Ghrita Guggulu. AYU; 31/1: 2010; 53-57.

25. Raman K. Pragya S. Janubasti and nadi-swedana in janu sandhigata vata: a case study. International journal of ayurvedic \& herbal medicine. 2015; 5(6): 2067-2071. 